\title{
Viral diarrhea in developing countries-Current scenario
}

\author{
Anita Chakravarti and Bineeta Kashyap \\ Department of Microbiology, Maulana Azad Medical College, New Delhi-2
}

\section{INTRODUCTION}

The impact of diarrheal disease worldwide is immense, with children under five years of age in developing countries are most often affected. ${ }^{1,2,3,4}$ In the developed world, the impact of the illness is seen in its high morbidity and hospitalization that this illness necessitates. ${ }^{5,67,8}$ Although targeted interventions like improved sanitation, breast-feeding and introduction treatment programs based on oral rehydration therapy, have decreased the mortality rate associated with infection due to bacterial and parasitic agents, they have been less effective in reducing viral-associated morbidity and mortality.

\section{HISTORICAL BACKGROUND \& ETIOLOGY}

The etiology of a major portion of diarrheal illnesses remained unknown until the 1950s, when the introduction of tissue culture technology led to the discovery of over 100 new viruses, many of which were isolated in faeces, but none of which could be implicated as an important etiologic agent of acute gastroenteritis. ${ }^{9,10,11}$ Currently, in up to 50\% of cases investigated for diarrhea no etiological agent is identified. Some viruses found in faeces are incidental findings while for other viruses the gut is only the portal of entry. Some viruses only cause diarrhea in the immunocompromised whereas diarrhea can be a common complication of other viral infections such as measles. Group C rotaviruses, Coronavirus, Picobirnavirus, Pestivirus and Torovirus, considered primary agents of gastroenteritis among animal species, are now recognized as emergent viruses associated with viral gastroenteritis in human patients. ${ }^{11}{ }^{11}$ The viruses which cause gastroenteritis are primarily from four distinct families: Group A rotaviruses, caliciviruses, enteric adenoviruses and astroviruses. ${ }^{12}$

Keywords: Diarrhoea, electron microscope, vaccines, viral gastroenteritis

\section{ROTAVIRUS}

Since their first description in 1973 by Bishop et al ${ }^{10}$ in the cytoplasm of duodenal epithelial cells from children with acute diarrhea, data on rotavirus infection predominate in the literature on viral diarrhea. ${ }^{13}$

Morphology \& Classification: Rotaviruses are members of the family Reoviridae and are characterized by segmented, double-stranded RNA and wheel like appearance. (Figure 1) The mature virus particles are triple layered, an outer capsid, an inner capsid and an internal core, approximately $70 \mathrm{~nm}$ in diameter and possess icosahedral symmetry. The rotavirus genome consists of 11 segments, that code for 6 structural viral proteins (VP1, VP2, VP3, VP4, VP6 and VP7) and 6

\section{Corresponding Author :}

Dr. Anita Chakravarti, Professor

Department of Microbiology

Maulana Azad Medical College, New Delhi - 110002.

E mail: anitachakravarti@yahoo.com

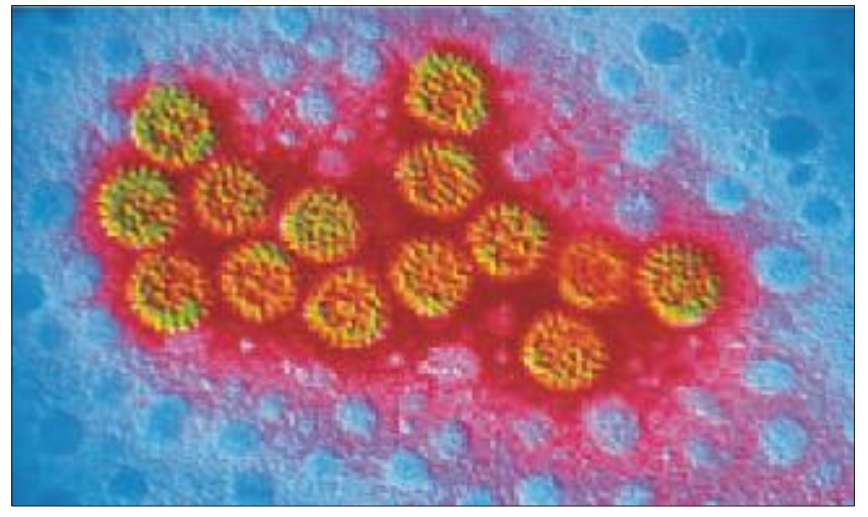

Figure 1: Coloured transmission electron micrograph of rotavirus particles, showing the characteristic wheel-like appearance (originalmagnification $x 48,500$ ).

non-structural proteins (NSP1 - NSP6), with gene segment 11 encoding both NSP5 and 6. (Table I) When mixed infection occurs, the gene segments from the parental viruses may reassort independently, producing reassortants of mixed parentage, a source of viral diversity. ${ }^{14}$ The genome is encompassed by an inner core consisting of VP2 with small amounts of VP1 and VP3 
Table I

Characteristics of structural \& non-structural rotavirus group A proteins ${ }^{1}$

\begin{tabular}{llll}
\hline $\begin{array}{l}\text { Genome } \\
\text { segment }\end{array}$ & Protein encoded & Viral particle localization & Function \\
\hline 1 & VP1 & Core & RNA polymerase \\
2 & VP2 & Core & RNA binding \\
3 & VP3 & Core & Guanilyltransferase \\
4 & VP4 & Outer capsid & Viral hemagglutinin, neutralization \\
& (VP5+VP8 subunits) & & antigen, P serotypes \\
& & & Proteolytic cell cleavage \\
5 & NSP1 & Non structural & RNA binding \\
6 & VP6 & Inner capsid & Group and subgroup antigen \\
$7,8,9$ & NSP3 & Non structural & RNA binding \\
$7,8,9$ & VP7 & Outer capsid & Glycoprotein (G serotypes), \\
& & & neutralization antigen \\
8 & NSP2 & Non structural & Viral replication \\
10 & NSP4 & Non structural & Enterotoxin-like activity, viral assembly \\
11 & NSP5 & Non structural & RNA binding \\
\hline
\end{tabular}

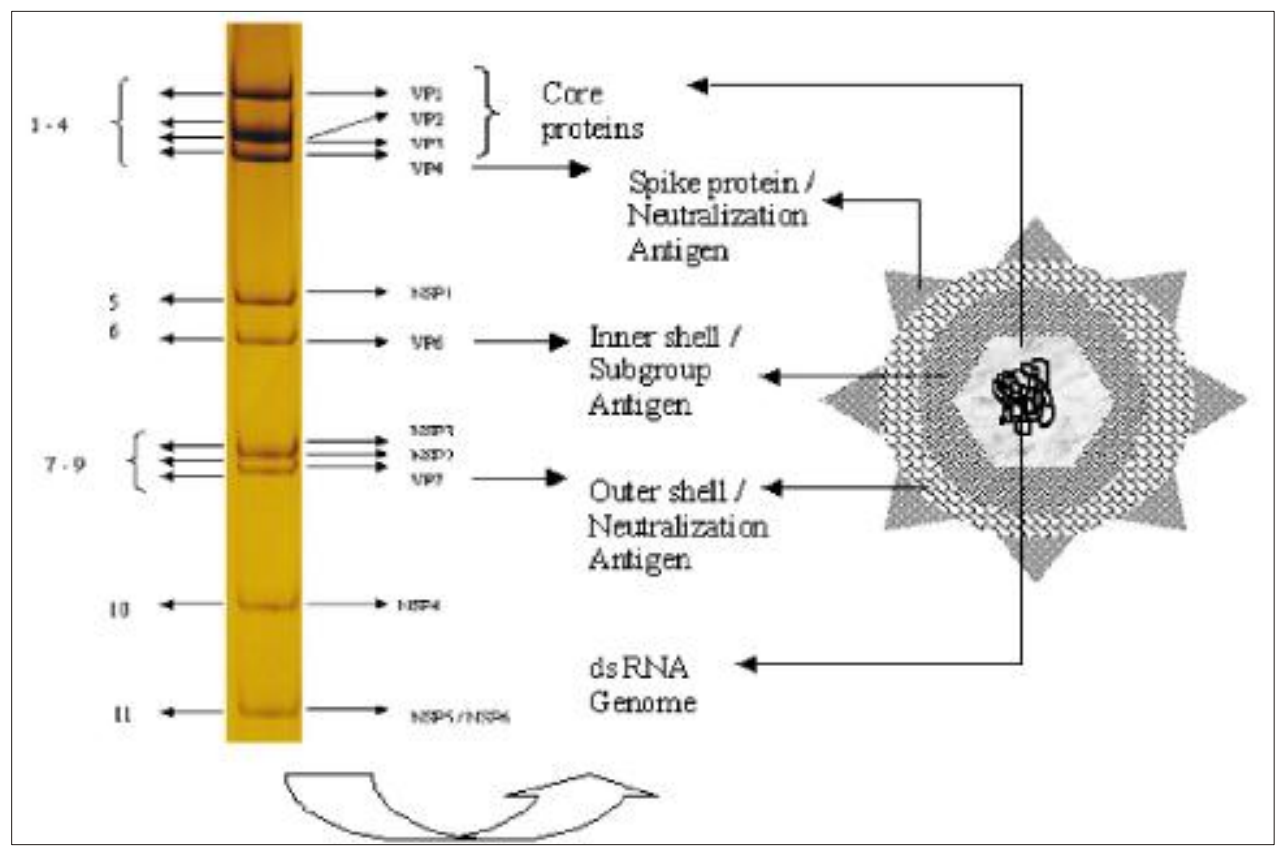

Figure 2. Structure of rotavirus. Coding assignments of 11 RNA segment (left) and schematic diagramofrotavirus (right). ${ }^{16}$ 
proteins. The intermediate layer or inner capsid is made of VP6, which determines group and subgrouping specificities. The outer capsid layer is composed of two proteins, VP7 and VP4 that elicit neutralizing antibody responses (Figure 2). The VP7 protein is glycosylated, and serotypes determined by this protein are termed $G$ serotypes. VP4 is a protease-cleaved protein, and serotypes determined by this protein are termed $\mathrm{P}$ serotypes. To date, $15 \mathrm{G}$ and $27 \mathrm{P}$ genotypes have been described. ${ }^{15}$ The classification of rotavirus into seven different groups (A-G) is based on the antigenic specificity of the VP6 capsid proteins as well as on the pattern of electrophoretic mobility of the 11 RNA segments of the viral genome. ${ }^{16}$

Pathogenesis: Since rotavirus infections are universal in children during the first few years of life; this suggests that the virus is not primarily transmitted through fecally contaminated food and water, therefore, rotavirus infection cannot be prevented solely through improvements in sanitation. ${ }^{17}$ Most cases are sporadic but nosocomial outbreaks are common in preschool children. Transmission from animals has been investigated but found to be rare in most parts of the world. Notable exceptions, however, are areas of Brazil and India, where human-porcine and human-bovine reassortment strains, respectively, have been found to be endemic. The mechanism that induces the production of diarrhea appears to be mediated by the relative decrease of villous epithelium absorption in relation to the secretory capacity of the crypt cells. ${ }^{1,18}$ It has been reported that the first infection with rotavirus elicits a homotypic neutralizing antibody response, with heterotypic responses in subsequent infections. ${ }^{19}$

Disease burden \& Epidemiology:Rotaviruses have been implicated as etiological agent of diarrhea in older children and adults. Only groups A to $\mathrm{C}$ have been shown to infect humans and most animals, with rotavirus disease mainly being caused by group A. Rotavirus accounts for $>22 \%$ of hospitalizations for childhood diarrhea and causes 440,000 annual deaths in children $<5$ years of age worldwide and that $82 \%$ of all such deaths occurs in developing countries. ${ }^{20}$ Approximately $17 \%$ $(100,000)$ of the world's estimated rotavirusassociated deaths, together with about 400,000 hospitalizations, occur each year in India making the development and testing of an effective RV vaccine a particular priority in India. ${ }^{15,21,22,23}$ During the first five years of life in USA, four out of five children will develop rotavirus diarrhea, but only one in 78 will be hospitalized and only one in 195,000 will die. In developing countries, however, a similar proportion will develop rotavirus diarrhea, but one in eight will develop severe illness and one in 160 will die. ${ }^{24}$

HRV shows extensive genomic variation, the extent of which depends on geographic location and duration of studies. Worldwide surveillance of rotavirus strains has demonstrated G1 to G4 to be the most common circulating $\mathrm{G}$ types. In the 1990s, a new genotype, G9, emerged in India and is now quite common worldwide. Several recent international studies have demonstrated a novel G12 rotavirus to be emerging as well. G5 rotaviruses, previously found only in pigs and horses, were detected in Brazilian children in 1983 and have since been regularly reported from Brazil at a high frequency. Similarly, G8 rotaviruses have been detected all over the African continent at a high frequency, especially in Malawi. ${ }^{15,25}$ The major human $\mathrm{G}$ types (G1, G2, G3 \& G4) which combined with $\mathrm{P}$ types (P[8], P[4] \& $\mathrm{P}[6])$ accounts for more than $80 \%$ of RV associated gastroenteritis episodes worldwide. ${ }^{26}$

A previous survey of strains collected from 6 centers in India observed 3 salient features: ${ }^{27}$

1. Serotype G9 was the most common serotype $(17 \%)$.

2. As many as eight different strains were circulated at the same time.

3. The prevalence of mixed infections with two or more different RV strains was high (11\%).

Another study done by the same authors later documented marked diversity of RV strains in circulation (mixed infection 21\%), a high prevalence of G9 \& P[6] and the presence of unusual strains ${ }^{28}$. The four globally common serotypes-P[8], G1; P[4], G2; P[8], G3; and $\mathrm{P}[8], \mathrm{G} 4$ - together accounted for only $43 \%$ of strains tested.

As far as comparison of rotavirus diarrhea among outpatients and hospitalized patients is concerned, the rate of rotavirus detection was higher among in-patients $(28.3 \%)$ than outpatients $(15.5 \%) .{ }^{29}$ Studies have reported that maternal antibodies and physiologic immaturity of the neonatal gut may play a role in the association of asymptomatic rotavirus infections in neonates with specific strains. ${ }^{30,}, 31$ 


\section{ENTERIC ADENOVIRUS}

Enteric adenoviruses (EAd) are considered as enteropathogens, detected world wide in sporadic and outbreak cases of gastroenteritis in different settings such as day care centers and hospitals. ${ }^{33,34,35}$

Morphology \& Classification: Human adenoviruses belong to the Adenoviridae family and are doublestranded DNA viruses without an envelope, $70 \mathrm{~nm}$ in diameter with icosahedric symmetry. ${ }^{36,37}$ The protein capsid is composed of 252 capsomers - 240 hexones and 12 pentones - and structures called fibers that protrude to the outside. The hexones contain proteins II, VI, VIII, and IX, which participate in the stability and assembly of the viral particle. The pentone proteins (III and IIIa) have the function of cellular penetration, and the fibers are hemagglutinins and are responsible for binding the virus to receptors. The enteric serotypes that are most frequently associated with gastroenteritis caused by adenovirus are 40 and 41 , which belong to subgenus $\mathrm{F}$. More rarely, serotypes 31, 12 and 18 of subgenus A and serotypes 1, 2, 5 and 6 of subgenus $C$ have been involved in the etiology of acute diarrhea. ${ }^{1}$

Pathogenesis \& Immune Response: Lesions produced by serotypes 40 and 41 in the enterocytes lead to atrophy of the villi and compensatory hyperplasia in the crypts. After the infection, specific antibodies develop in most cases, and non-neutralizing antibodies are useful for measuring the immune response. ${ }^{1}$

Disease burden and Epidemiology: To date, more than 51 human adenovirus serotypes have been identified and adenovirus type 40 and 41 , has been found to be associated with acute gastroenterititis and occupies 1$20 \%$ cases of diarrheal disease. ${ }^{35,38}$ On the basis of enzyme immunoassay (EIA) techniques, EAds were found to be present in 0.9 to $33.3 \%$ of stool specimens collected from infants with diarrhea, with lower rates generally reported from developing countries ( 0.9 to $13.9 \%$ ). Other studies using similar reagents (i.e., specific monoclonal antibodies) for detection of enteric serotypes have found similar rates of excretion among diarrhea cases in developing countries, whereas studies in developed and some developing countries have found much higher rates of detection. ${ }^{39,40} \mathrm{~A}$ very recent study done on hospitalized patients from 3 cities in India to identify the most prevalent strains of EAds by PCR and sequencing indicated the overall positivity of EAds at $7.8 \%$ level being significantly higher in children $<24$ months of age. ${ }^{38}$

\section{ASTROVIRUS}

The medical importance of human astrovirus (HAstV) infection has been established by reports showing that in some settings astroviruses are second only to rotavirus as a common cause of viral gastroenteritis in infants and young children. ${ }^{41,42}$

Morphology \& Classification: Astrovirus has been reported as small round viruses of $28-30 \mathrm{~nm}$ with an appearance like that of a five- or six-pointed star by direct visualization with electron microscopy. However, it has recently been verified that this virus has a different morphology with an icosahedric appearance, a diameter of $41 \mathrm{~nm}$ and well defined spikes. When these viruses are subjected to a high $\mathrm{pH}$, they present the typical morphology of the initially described star. ${ }^{1}$ The genome of human astroviruses is composed of single-stranded, positive-sense RNA which contains three 'open reading frames' (ORFs). Astroviruses are classified into serotypes based on the reactivity of the capsid proteins. Serotyping and genotyping have identified at least eight types of astrovirus, with type 1 being the most prevalent. Typing of eight astrovirus strains from a French outbreak situation showed five types, so co circulation occurs ${ }^{43}$.

Pathogenesis \& Immune Response: The pathogenesis of the disease induced by astrovirus has not yet been established, although, in animal studies, atrophy of the intestinal villi is observed. Symptomatic astrovirus infection occurs mainly in small children and the elderly, which suggests a reduction in antibodies in recent years, but the determinants of immunity are not well known. Trials with monoclonal antibodies against human astrovirus suggest that VP26 and/or VP29 may be important in the neutralization, heterotypic immunity and binding of the virus to the target cells. ${ }^{44}$

Disease burden \& Epidemiology: Recent studies confirmed HAstVs as a worldwide cause of diarrhea, mainly among young children. Large outbreaks of gastroenteritis associated with HAstV infection have been reported in children's day care centers and schools as well as in elderly homes. HAstV infections generally result in disease with low severity. Type 1 is the most prevalent type identified worldwide, although detection of the other types is increasing. Mixed infections involving HAst $\mathrm{V}$, rotavirus, norovirus and adenovirus are often seen. ${ }^{45}$ In developed countries, this virus has been associated with 4 to $10 \%$ of endemic diarrheal episodes in children. ${ }^{46,47}$ Studies on infants hospitalized withacute 
diarrhea have identified rates between 2 to $5 \%$ in India, Brazil, Australia and Argentina. ${ }^{46,48}$

\section{CALCIVIRUS}

In the early 1970s, a filtrate made from a rectal swab specimen from a secondary case of gastroenteritis from an outbreak of "winter vomiting disease" that affected about $50 \%$ of the students and teachers in an elementary school in Norwalk, Ohio, was found to induce gastroenteritis in adult volunteers. This illness inducing filtrate was designated as the "Norwalk agent" Many outbreaks of gastroenteritis in adults are attributed to small round structured viruses (SRSVs), the first to be recognized, with the application of immune electron microscope (IEM), as a cause of epidemic non bacterial gastroenteritis was Norwalk virus named after the town in which the outbreak took place in 1968. ${ }^{9,49}$ This virus, along with other SRSVs described as Norwalk-like viruses (eg Southampton virus) are classified as members of the Caliciviridae family. Taxonomic changes in 2002 renamed Norwalk-like viruses as Norovirus. Noroviruses have emerged as the single most common cause of outbreak as well as sporadic cases of acute gastroenteritis in children and adults after rotavirus. Another group of caliciviruses, including Sapporo virus, described previously as Sapporo-like viruses have been renamed as Sapovirus. Chiba et al described a typical calcivirus, associated with gastroenteritis, in infants and children living in an infant home in Sapporro, Japan in 1977 which was found to be antigenically distinct from Norwalk viruses by IEM. The caliciviruses are RNA viruses that cannot be cultivated in cell culture. The Norovirus and Sapovirus belong to family calciviridae and are commonly referred to as human calciviruses (HuCVs).

Morphology \& Classification: Human caliciviruses are members of the Caliciviridae family, and two genera have been described, the Norwalk-like viruses (NLVs) and Sapporo-like viruses (SLVs). The virions are composed of a single structural capsid protein with icosahedric symmetry. This protein, composed of 180 molecules, folds into 90 dimers, which form a continuous shell with protrusions in the shape of an arch. A key characteristic is the existence of 32 cup-shaped depressions, situated on the axes of the icosahedron, from whose Latin designation, calyx, the virus derives its name. The genome of the NLVs consists of positive-sense, single-stranded RNA organized into three ORFs. The genome of the SLVs differs from the NLV genome in that the ORF1 encodes the non-structural proteins as well as the structural protein of the capsid. The human caliciviruses genera (NLVs and SLVs) can be further divided into genetic clusters. The NLVs include Norwalk virus (the type species), Desert Storm virus, Southampton virus, Snow Mountain agent, Hawaii virus, Toronto virus, Bristol virus and Jena virus. The SLVs includes Sapporo virus (the type species), Parkville virus and London virus. ${ }^{1}$ Genotyping divides the caliciviruses into three groups and serotyping yields at least five groups represented by norovirus, Hawaii virus, Snow Mountain agent, Taunton agent and sapovirus.

\section{PATHOGENESIS \& IMMUNE RESPONSE}

Transmission of caliciviruses is through the faecal-oral route, in common with other virus groups that cause diarrhea. However, the spread of norovirus is enhanced by aerosol production as a result of the projectile vomiting that is a feature of the infection. The viruses are resistant to drying and also to the disinfectants that are deemed suitable for upholstered surfaces. This hampers control of outbreaks in locations such as nursing homes for the elderly and on cruise ships. Foodborne outbreaks tend to be traced to cold foods such as salads, while waterborne outbreaks can be linked to recreational or drinking water. Noroviruses are the most infectious agents ever described, with an estimated median infectious dose of 18 viruses. Furthermore, norovirus shedding can occur at extremely high levels and can persist for weeks after the symptoms have resolved.

Disease burden \& Epidemiology: Norovirus is a major cause of viral gastroenteritis worldwide, accounting for at least $28 \%$ of all foodborne outbreaks. ${ }^{50}$ Although the disease is usually perceived as mild and self-limiting, protracted diarrhea and serious complications may develop in elderly or immunocompromised patients. ${ }^{51}$ The majority of outbreaks associated with norovirus involve older children and adults, particularly in institutional settings. In contrast, those associated with sapovirus occur in the paediatric setting. A survey covering eight countries revealed that in 11 of 12 studies a seasonal peak occurred during the cooler months. ${ }^{53}$ This coincides with the rotavirus peak in temperate climates. No virus accounted for $12 \%$ of severe gastroenteritis cases among children $<5$ years of age and $12 \%$ of mild and moderate diarrhea cases among persons of all ages. Of 19 studies among children $<5$ years of age, 7 were in developing countries where pooled prevalence of severe NoV disease (12\%) was comparable to that for industrialized countries (12\%). Since the application of molecular assays, NoVs have 
been well-documented as the leading cause of epidemic gastroenteritis in all age groups, causing $>90 \%$ of nonbacterial and $>50 \%$ of all-cause epidemic gastroenteritis worldwide.

\section{OTHER GASTROENTERITIS-PRODUCING VIRUSES}

\section{TOROVIRUS}

Torovirus is a genus within the Coronaviridae family. Torovirus, detected first in 1984, have an envelope of 100-140 nm, with a capsid of helicoidal symmetry and a single-stranded RNA genome of positive sense. They are associated with persistent and acute diarrhea in children and may represent an important cause of nosocomial diarrhea. ${ }^{1}$

\section{CORONAVIRUS}

Coronaviruses are 80 to $150 \mathrm{~nm}$ enveloped, medium-sized, positive stranded RNA viruses that were first discovered in patients with upper respiratory tract illness. These viruses have also been associated with diarrheal diseases in mammals, especially newborns. They are seen as rounded or pleomorphic particles that have club-shaped projections on their surface, called peplomers giving the appearance of the corona of the sun. Coronavirus have been observed in the stools of normal individuals as well as in diarrheal or necrotizing enterocolitis stools, so that its role in gastrointestinal disease has been questioned. ${ }^{1}$

\section{PICOBIRNAVIRUSES}

These are small viruses, without an envelope, $30-40 \mathrm{~nm}$ in diameter, with a capsid of icosahedric symmetry and a genome made up of two or three segments of bicatenary RNA. They were identified for the first time by Pereira et al. in 1988. Since then, they have been found in a wide variety of animal species and in both children and adults with diarrhea, including immunosuppressed patients. ${ }^{1}$

\section{CLINICAL PRESENTATION OF VIRAL GASTROENTERITIS}

Viral gastroenteritis is a self-limiting process which may sometimes become persistent. Several studies have also shown the asymptomatic elimination in feces of adenovirus and astrovirus, and it is calculated that about $50 \%$ of infections by calicivirus are asymptomatic. ${ }^{1}$ The severity of the infection, together with the need for hospitalization, is greater with gastroenteritis caused by group A rotavirus than with that associated with adenovirus, astrovirus or calicivirus. The majority of symptomatic infections occur in children under five. Incubation period is short (usually 12-24 hours) and the onset of diarrhea is sudden. One three-year study of Guatemalan children showed that dehydration was 14 times more frequent with rotavirus infection than with bacterial or parasitic diarrhea. ${ }^{53}$ Rotavirus infection is a seasonal phenomenon in temperate climates, with peaks in the colder months. Clinical presentation of enteric adenovirus can be mistaken for rotavirus infection but the incubation period is longer (8-10 days) and the symptoms can last longer (usually 5-12 days). The disease is usually mild and the 12-24 month age group is most commonly affected. However, adenovirus infection does not exhibit seasonal trends. The incubation period for calcivirus infection varies from 10 to 50 hours and the diarrhea lasts for 12-24 hours. The majority of outbreaks associated with norovirus involve older children and adults, particularly in institutional settings. In contrast, those associated with sapovirus occur in the pediatric setting. A comparison of the two virus groups in Finnish children showed that the predominant clinical feature of norovirus infection was vomiting while for sapovirus infection it was diarrhea. ${ }^{55}$ The diarrhea is generally mild and selflimiting. Most studies of outbreaks revealed a seasonal peak occurred during the cooler months that coincide with the rotavirus peak in temperate climates. Astroviruses have a tendency to symptomatically infect children, immunocompromised individuals or the elderly. Symptoms in children can be mistaken for those of rotavirus infection, although the diarrhea is milder, watery and not associated with severe dehydration in otherwise healthy patients. Incubation period is 12-24 hours in children, but slightly longer in adults. The diarrhea lasts for two to three days and accompanying symptoms such as vomiting usually resolve within four days. Astroviruses exhibit a seasonal peak that corresponds with the cooler months in temperate regions and with the rainy season in tropical areas.

The viruses that produce gastroenteritis represent an important cause of nosocomial infection in pediatric admission units due to the many asymptomatic patients who eliminate the virus in feces and the environmental contamination that accompanies the relative resistance of these viruses to normal disinfectants and nosocomial diarrhea has been described in $2-6 \%$ of children admitted. $^{54}$ 


\section{LAB DIAGNOSIS OF VIRAL GASTRO- ENTERITIS}

Traditionally the diagnosis of viral infections has relied upon (i) identification of virus in host tissue, (ii) isolation of virus in a secondary host system such as cultured cells or fertile hen eggs, or (iii) demonstration of a virus-specific antibody response. Cell culture is technically cumbersome and slow and yet to be achieved for calicivirus, human torovirus or coronavirus. Serology is also of little use in rapid diagnosis because a specific antibody response occurs too late in most cases. This has given rise to an ironic situation whereby we have become dependent upon the time-honoured art of electron microscopy and file technical innovations of immunology and molecular biology.$^{56}$ Electron microscopy remains the reference method for the diagnosis of viral gastroenteritis though it is limited to reference laboratories. Besides, for some agents such as astrovirus and calicivirus there is no other method that is widely available. Some viruses, such as the rotaviruses and adenoviruses, are shed in large numbers and also have the advantage of being sufficiently distinctive by EM. In contrast, norovirus do require confirmation, as many other particles in fecesare of a similar size. Use of enzyme linked immunosorbent assay (ELISA) technology became widespread during the 1980s, followed by sensitive techniques for antigen detection in feces based on EIA, agglutination with latex particles (LA) and, more recently, immunochromatography (ICG) and molecular biology techniques in the 1990s. ${ }^{57-59}$ PCR techniques have promise, although their use currently seems to be limited to research laboratories. ${ }^{60-62}$ Whichever detection method is employed, it must be remembered that the presence of a virus does not necessarily correlate with infection. Furthermore, dual infection may be a feature of viral diarrhea. Progress in the diagnosis of gastroenteritis viruses will depend equally upon the refinement of existing techniques and the development of novel diagnostic tests.

\section{MANAGEMENT \& PREVENTION OF VIRAL GASTROENTERITIS}

Interruption of transmission in viral gastroenteritis of the infection is extremely important, therefore, it is necessary to reinforce hygiene measures.

Fastidious adenovirus infection is not as common or as serious as rotavirus infection and therefore the need for an adenovirus vaccine is not as pressing, with no candidate vaccines reported thus far. To date, a lack of understanding about immunity to caliciviruses and failure of propagation in vitro has been an obstacle to vaccine development. However, genotype II, cluster 4 NoV strains appeared to be by far the most prevalent strains among the studies and these strains may be the primary targets for vaccine development. The mild nature of the illness caused by astrovirus has not warranted significant research efforts towards production of vaccines.

\section{ROTAVIRUS VACCINES: AN OVERVIEW ${ }^{63}$}

Growing recognition of the importance of rotavirus disease and high visibility and abortive history of the introduction and withdrawal of RotaShield (vaccine associated intussusception), the first licensed rotavirus vaccine, have resulted in renewed interest in the prevention of rotavirus disease through the use of vaccine. In 2006, the results of pivotal clinical trials of two new rotavirus vaccines - RotaTeq (Merck) and Rotarix (GlaxoSmithKline) - were published and high efficacy (85 to $98 \%$ ) against severe rotavirus diarrhea was reported for both products.

\section{RATIONALE FOR ROTAVIRUS VACCINES:}

* Rotavirus infection is universal in children during the first few years of life and is the most common cause of severe illness.

* Patients with rotavirus infection often present with severe vomiting, a symptom that frequently prompts parents to discontinue oral rehydration therapy, and breast-feeding is not effective in diminishing the severity of disease.

* Although first infections can lead to disease, they also can induce immunity against severe disease after reinfection.

Rotarix is derived from a single human rotavirus strain (89-12; P1A[8],G1) that was attenuated by multiple passages in cell culture. RotaTeq is composed of 5 rotavirus strains, each of which is a single-gene reassortant based on a parent bovine strain (WC3) A vaccine based on a lamb strain is licensed in China. Manufacturers in India (Bharat Biotech) and Indonesia (Bio Farma) have naturally occurring neonatal strains that are being considered as candidate vaccines. ${ }^{17}$ The two Indian neonatal candidate vaccines appear to be natural bovine-human reassortants are 116E, a G9P[11] rotavirus isolated from neonatal nurseries in Delhi and I321, a G10P[11] rotavirus described from Bangalore. 


\section{REFERENCES}

1. Wilhelmi I, Roman E, Sanchez-Fauquier A. Viruses causing gastroenteritis. Clin Microbiol Infect 2003;9(4):247-62.

2. Glass RI, Kilgore PE. Etiology of acute viral gastroenteritis. In: Diarrheal disease. Nestle Nutrition Workshop Series. Gracey M, Walker JA. Philadelphia: Lippincott-Raven, 1997:39-54.

3. Snyder JD, Merson MH. The magnitude of the global problem of acute diarrheal disease: a review of active surveillance data. Bull WHO 1982;60:605-13.

4. Kosek M, Bern NC, Guerrant RL. The global burden of diarrheal disease, as estimated from studies published between 1992 and 2000. Bull WHO 2003;81(3):197-204.

5. Christensen ML. Rotaviruses.In: Murray PR, Baron EJ, Pfaller MA, Tenover FC, Yolken RH, editors. Manual of clinical microbiology. Washington: ASM Press; 1999. p. 999-1004.

6. Glass RI, Lew JF, Gangarosa RE, LeBaron CW, Ho MS. 1991. Estimates of morbidity and mortality rates for diarrheal diseases in American children. J Pediatr 118:S27-33.

7. Clarke SC.diarrheal disease in childhood - an ongoing global problem. Biomedical Scientist 2001;45(12):1317-9.

8. Nguyen TV, Le Van P, Le Huy C, Weintraub A. Diarrhea Caused by Rotavirus in Children Less than 5 Years of Age in Hanoi, Vietnam. J Clin Microbiol 2004;42(12):5745-50.

9. Kapikian AZ, Wyatt RG, Dolin R, Thornhill TS, Kalica AR, Chanock RM. Visualization by immune electron microscopy of a $27 \mathrm{~nm}$ particle associated with acute infectious non-bacterial gastroenteritis. J Virol 1972;10:1075-81.

10. Bishop RF, Davidson GP, Holmes IH, Ruck BJ. Virus particles in epithelial cells of duodenal mucosa from children with acute non bacterial gastroenteritis. Lancet 1973;2:1281-3.

11. Ospino DU, Young G, Navarro OA. Viral gastroenteritis and diversity of rotavirus strains in Colombian children: a systematic review. J Infect Dev Ctries 2008;2(2):99-105.

12. Andreasi MS, Cardoso DD, Fernandes SM, Tozetti IA, Borges AM, Fiaccadori FS, et al. Adenovirus, calicivirus and astrovirus detection in fecal samples of hospitalized children with acute gastroenteritis from Campo Grande, MS, Brazil. Mem Inst Oswaldo Cruz 2008;103(7):741-4.

13. Prasad BVV, Estes MK. Electron cryomicroscopy and computer image processing techniques: use in structurefunction studies of rotavirus. In: Gray JJ, Desselberger U, editors. Rotavirus methods and protocols. New Jersey: Humana Press; 2000 p. 932.

14. Desselberger U. Genome rearrangements of rotaviruses. Arch Virol Suppl 1996;12:37-51.

15. Sharma S, Ray P, Gentsch JR, Glass RI, Kalra V, Bhan MK. Emergence of G12 Rotavirus Strains in Delhi, India, in 2000 to 2007. J Clin Microbiol 2008;46(4):1343-8.

16. Ramani S, Kang G. Burden of disease \& molecular epidemiology of group A rotavirus infections in India. Indian J Med Res 2007;125(5):619-32.

17. Glass RI, Bresee JS, Turcios R, Fischer TK, Parashar UD, Steele AD. Rotavirus Vaccines: Targeting the Developing World. J Infect Dis 2005; 192:S160-6.
18. Salim AF, Phillips AD, Walker-Smith JA, Farthing MJG. Sequential changes in small intestinal structure and function during rotavirus infection in neonatal rats. Gut 1995;36(2):231-8.

19. Colomina J, Raga J, Gil MT, Buesa J. Virus-specific serum and fecal antibodies response in children with acute rotavirus gastroenteritis. Enferm Infecc Microbiol Clin 1998;16(2):5560.

20. Parashar UD, Hummelman EG, Bresee JS, Miller MA, Glass RI. Global illness and deaths caused by rotavirus disease in children. Emerg Infect Dis 2003;9(5):565-72.

21. Jain V, Parashar UD, Glass RI, Bhan MK. Epidemiology of rotavirus in India. Indian J Pediatr. 2001;68:855-62.

22. Chakravarti A, Rawat D, Chakravarti A. Molecular epidemiology of rotavirus in Delhi. Indian J Pathol Microbiol 2004;47(1): 90-3.

23. Bresee J, Fang ZY, Wang B, Nelson EAS, Tam J, Soenarto Y et al. First report from the Asian Rotavirus Surveillance Network. Emerg Inf Dis. 2004;10:988-95.

24. Centers for Disease Control. Recommendations and reports: rotavirus vaccine for the prevention of rotavirus gastroenteritis among children. Recommendations of the Advisory Committee on Immunization Practices (ACIP). MMWR Morb Mortal Wkly Rep 1999;48:1-20.

25. Banerjee I, Ramani S, Primrose B, Moses P, Iturriza-Gomara M, Gray JJ et al. Comparative Study of the Epidemiology of Rotavirus in Children from a Community-Based Birth Cohort and a Hospital in South India. J Clin Microbiol 2006;44(7):2468-74.

26. Santos N, Hoshino Y. Global distribution of rotavirus serotypes/ genotypes and its implication for the development and implementation of an effective rotavirus vaccine. Rev Med Virol 2005;15(1):29-56.

27. Das BK, Kumar RK, Bhan MK. Rotavirus gastroenteritis and vaccine development Indian J Pediatr 1998;65:S36-44.

28. Jain V, Das BK, Bhan MK, Glass RI, Gentsch JR.The Indian Strain Surveillance Collaborating Laboratories. Great Diversity of Group A Rotavirus Strains and High Prevalence of Mixed Rotavirus Infections in India. J Clin Microbiol 2001;39(10):35249.

29. Kelkar SD, Purohit SG, Boralkar AN, Verma SP. Prevalence of rotavirus diarrhea among outpatients and hospitalized patients: a comparison. Southeast Asian J Trop Med Public Health 2001;32(3):494-9.

30. Haffejee IE. Neonatal rotavirus infections. Rev Infect Dis 1991;13(5):957-62.

31. Glass RI, Bhan MK, Ray P, Bahl R, Parashar UD, Greenberg H et al. Development of candidate rotavirus vaccines derived from neonatal strains in India. J Infect Dis 2005;192(Suppl 1):S30-5.

32. Dennehy PH. Rotavirus Vaccines: an Overview. Clin Microbiol Rev 2008;21(1):198-208.

33. Van R, Wun CC, Oryan ML, Matson DO, Jackson L, Pickering LK. Outbreaks of human enteric adenovirus types 40 and 41 in Houston day care centers. J Pediatr 1992;120 (4 Pt1): 516-21.

34. Akihara S, Phan TG, Nguyen TA, Hansman G, Okitsu S, 
Ushijima H. Existence of multiple outbreaks of viral gastroenteritis among infants in a day care center in Japan. Arch Virol 2005;150(10):2061-75.

35. Shimizu H, Phan TG, Nishimura S, Okitsu S, Manee N, Ushijome $\mathrm{H}$. An outbreak of adenovirus serotype 41 infection in infants and children with acute gastroenteritis in Maizura City, Japan. Infect Genet Evol 2007;7(2):279-84.

36. Morris CA, Flewett TH, Bryden AS, Davies H. Virus particles in gastroenteritis? Epidemic viral enteritis in a long-stay children's ward. Lancet 1975;1(7895):4-5.

37. Brown M, Grydsuk JD, Fortsas E, Petric M. Structural features unique to enteric adenoviruses. Arch Virol Suppl 1996;12:301-7.

38. Verma H, Chitambar SD, Varanasi G. Identification and Characterization of Enteric Adenoviruses in Infants and Children Hospitalized for Acute Gastroenteritis. J Med Virol. 2009;81(1):60-4.

39. Khan KJ, Tzipori SR, Unicomb LE. Enteric Adenovirus Infection among Infants with Diarrhea in Rural Bangladesh. J Clin Microbiol 1993;3(3):484-9.

40. Tiemessen CT, Wegerhoff FO, Erasmus MJ, Kidd AH. Infection by enteric adenoviruses, rotaviruses and other agents in a rural African environment. J Med Virol 1989;28(3):176-82.

41. Madeley CR, Cosgrove BP. 28-nm particles in feces in infantile gastroenteritis. Lancet 1975;2(7932):451-2.

42. Glass RI, Noel J, Mitchell D, Herrmann JE, Blacklow NR, Pickering LK et al. The changing epidemiology of astrovirusassociated gastroenteritis: a review. Arch Virol Suppl 1996;12:287-300.

43. Chikhi-Brachet R, Bon F, Toubiana L, Pothier P, Nicolas JC, Flahault A et al. Virus diversity in a winter epidemic of acute diarrhea in France. J Clin Microbiol 2002;40(11): 4266-72.

44. Bass DM, Upadhyayula U. Characterization of human serotype 1 astrovirus-neutralizing epitopes. J Virol 1997;71(11):8666-71.

45. Gabbay YB, Chamone CB, Nakamura LS, Oliveira DS, Abreu SF, Cavalcante-Pepino EL et al. Characterization of an astrovirus genotype 2 strain causing an extensive outbreak of gastroenteritis among Maxakali Indians, Southeast Brazil. J Clin Virol 2006;37(4):287-92.

46. Giordano MO, Martinez LC, Isa MB, Paez RM, Nates SV. Childhood astrovirus-associated diarrhea in the ambulatory setting in a public hospital in Cordoba city, Argentina. Rev Inst Med Trop Sao Paulo 2004;46(2):93-6.

47. Guerrero ML, Noel JS, Mitchell DK, Calva JJ, Morrow AL, Martinez $\mathrm{J}$ et al. A prospective study of astrovirus diarrhea of infancy in Mexico City. Pediatr Infect Dis J 1998;17(8):723-7.

48. Shetty M, Brown TA, Kotian M, Shivananda PG. Viral diarrhoea in a rural coastal region of Karnataka, India. J Trop Pediatr 1995;41(5):301-3.
49. Adler JL, Zickl R. Winter vomiting disease. J Infect Dis 1969;119(6):668-73.

50. Atmar RL, Estes MK. The epidemiologic and clinical importance of norovirus infection. Gastroenterol Clin North Am 2006;35(2):275-90.

51. Lee N, Chan MC, Wong B, Choi KW, Sin W, Lui G et al. Fecal viral concentration and diarrhea in norovirus gastroenteritis. Emerg Infect Dis 2007;13(9):1399-401.

52. Mounts AW, Ando T, Koopmans M, Bresee JS, Noel J, Glass RI. Cold weather seasonality of gastroenteritis associated with Norwalk-like viruses. J Infect Dis 2000;181(2): S284-7.

53. Wyatt RG, Yolken RH, Urrutia JJ, Mata L, Greenberg HB, Chanock RM et al. Diarrhea associated with rotavirus in rural Guatemala: a longitudinal study of 24 infants and young children. Am J Trop Med Hyg 1979;28(2):325-8.

54. Bennet R, Hedlund KO, Ehrnst A, Eriksson M. Nosocomial gastroenteritis in two infant wards over 26 months. Acta Paediatr 1995;84(6):667-71.

55. Pang XL, Honma S, Nakata S, Vesikari T. Human caliciviruses in acute gastroenteritis of young children in the community. J Infect Dis 2000;181(2):S288-94.

56. Beards GM. Laboratory diagnosis of viral gastroenteritis. Eur J Clin Microbiol Infect Dis 1988;7(1):11-3.

57. Dennehy PH, Gauntlett DR, Spangenberger SE. Choice of reference assay for the detection of rotaviruses in fecal specimens: electron microscopy versus enzyme inmunoassay. J Clin Microbiol 1990;28:1280-3.

58. Thomas EE, Puterman ML, Kawano E, Curran M. Evaluation of seven immunoassays for detection of rotavirus in pediatric stool samples. J Clin Microbiol 1988;26:1189-93.

59. Wilhelmi I, Colomina J, Martín-Rodrigo D, Román E, SánchezFauquier A. New immunochromatographic method for rapid detection of rotaviruses in stool samples compared with standard enzyme immunoassay and latex agglutination techniques. Eur J Clin Microbiol Infect Dis 2000;20:741-3.

60. Jiang X, Wilton N, Zhong WM, Farkas T, Huang PW, Barrett E et al. Diagnosis of human caliciviruses by use of enzyme immunoassays. J Infect Dis 2000;181(2):S349-59.

61. Jiang X, Matson DO, Cubitt WD, Estes MK. Genetic and antigenic diversity of human caliciviruses (HuCVs) using RT-PVR and new EIAs. Arch Virol Suppl 1996;12:25162.

62. Gentsch JR, Woods PA, Ramachandran M, Das BK, Leite JP, Alfieri A et al. Review of $\mathrm{G}$ and $\mathrm{P}$ typing results from a global collection of rotavirus strains: implications for vaccine development. J Infect Dis 1996;174(suppl1):S30-6.

63. Penelope H. Dennehy. Rotavirus Vaccines: an Overview. Clin Microbiol Rev 2008;21(1):198-208. 


\section{PDF created with pdfFactory Pro trial version www.pdffactory.com}

